TITLE: MICROPROCESSOR BASED SYSTEM FOR ROLL-DOWN AND ACCELERATION TESTS
AUTHOR(S):
D. K. Lynn, C. Derouin, and P. Lamar

SUBMITTED TO: The Institute of Electrical and Electronics Engineers, Inc., 29th Vehicular Technology Conference, Arlington, Illinois, March 28, 29, \& 30, 1979, for presentation and publication.

By acceptance of this article, the publisher recuguizes that the U.S. Goveinment retains a nonexclusive, roydly-free license to publish or repro duce the published form of this contribution, or to allow others to do s.), for U.S. Govermment purposes.

The Los Alamos Scientiflc laboritory requests that the publisher identify this article as work performed under the auspices of the Department of Energy.

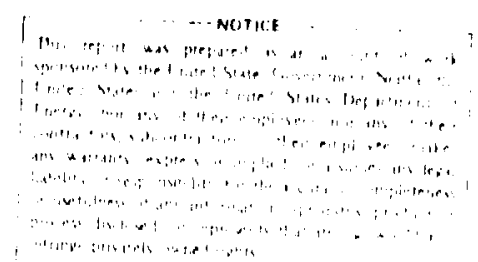




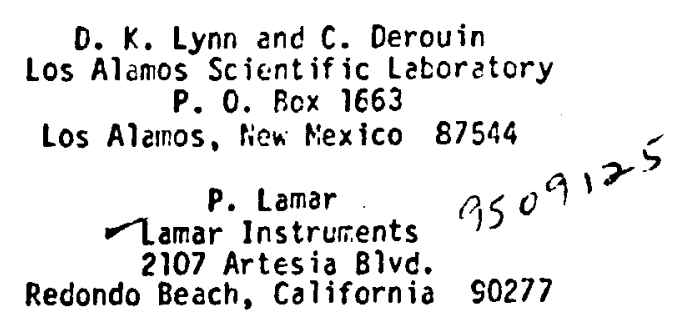

A microprocessor-based, road-test system for measuring and recorcing roll-dowin and acceleration data has been cesigned and built. The system provices for rapid testing of vehicles, can be operated by a single individual, and allow's detailed data acquisition vihen required. Digital data storage and output capability allows direct exchange of dita with other computers or calculators for data enalys is and recuction. System input is distance from a fifth wheel and elapsed time. The microcomputer system records time to the nearest 0.01 second, distance to the nearest fcct, and calcu. lates velocity to the $n \in$ arest 0.1 mile per inour. Data can be stored at specified time, distance, and velocity intervais. Current tire, distance, and velocity are displayed or a liquid crystal display oanel. A printing calculator prints a surmary of the run. Detailed data is stored in RAM anc is output to magnetic tape at the enc of the run. The tapes are used to obtain plots and as input for cata reduction programs that calculate rollins friction and aerodynamic drag. The road-test system has been used to test a number of vehicles. In most of the tests one person drove the vehicle and operated the system.

\section{Hardware Configuration}

A simplified block diagram of the road-test system is shovin in Fig. 1. The primary input to the system is 100 pulses/ft from the $f$ if th wheel. These pulses are divided by $1 \mathrm{CO} f \mathrm{cr}$ the distance counter and fed to a $8 C D$ counter for the velocity calculation. Tis remaining inputs are provice by tro timers and the status stitches. The tine counter is updated every 10 nis. Velocity is determined by reading the ECD counter every $68 \mathrm{~ms}$. Then

$v=\frac{N / 100}{0.068} \times \frac{60}{88}=\frac{N}{10} \mathrm{mph}$.

where $N$ is the number of counts.

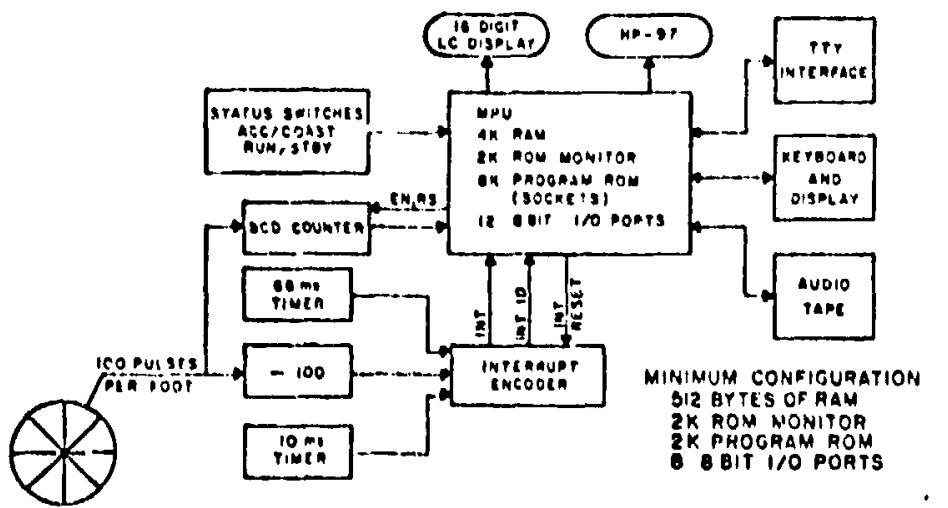

Fig. 1. Simplified diagrall of Lamar instruments roadtest system.
The status switches define whether an acceleration or coast-¿ckin run is required and whether the system is in the run or standby condition. A coast-dcwn run begins when the run/stariby status is changed from standby to run. An acceleration run tegins automatically when the foot counter reaches one foot.

The trio timers and the foot counter interrupt the microprocessor so that it can update tine, distance, or velocity. The timers interrupt at $10-$ and $68-\mathrm{ms}$ intervals; the foot counter interrupts at

$T_{v}=\frac{1}{v} \frac{60}{88}=\frac{0.68}{v} \mathrm{~s}$.

For $v=100 \mathrm{~m} . \mathrm{ph}$, the foot counter interrupts the processor every $6.6 \mathrm{~ms}$ and the 3 interrupts occur every $3.82 \mathrm{~m} . \mathrm{s}$ on the average. The external status sw: itches are read during initialization, in the background program, and inmediately after each interrupt.

The highest priority is assigned to the 68-ms timer, which is the rost critical interrupt. The $B C D$ counter must be disabled, read, reset, then enabled at precise intervels in orcer to give eccurate velocity readings. The disable, read, reset, enable sequence takes $22 \mu \mathrm{s}$, or about $0.03 \%$ of the EE-rs count time. As long as the 10-ms timer (and foot counter) are updated before the next time interval (or foot) occurs, there is no error accumulation in time (or distance).

The system diagram of Fig. 2 incluces a more detailed cescription of the processing unit. The processing unit contains a 105 7echnclogy 6502 mic-oprocessor, $4 K$ bytes of read/write memory, sockets for up to $E K$ bytes of program read-only memory, trielve 8-bit $1 / 0$ ports, 10 tirrers, 4 chift registers, and a $2 \mathrm{~K}$ byte monitor stored in RONi. The roaci-test system requires 512 bytes of RAM (2K to $4 K$ bytes for det cilled data storage), $2 K$ tytes of program RON, eight 8 -bit $1 / 0$ ports, 3 timers, and the ZK-byte RON monitor. The remaining capacity can be used for an expanded vehicle instrument ation system.

System output is provided by a 16-digit liquid crystal disploy and by the printer on an HP-97 printing calculater. The LC display is normally placed on the vehicle ciashtoard and displays elapser! time, current velocity, and elapsed distance. The HP-97 prints elapsed time, velocity, and clupsed distance at specifled times, velocities, and cistances. For acceleretion runs the printer prints at 10 and $20 \mathrm{~s}$; at each $10-m p h$ interval; and at 100,300,500, 900, 1320, and $1400 \mathrm{ft}$. The print points for coast conn are 10,20 50, 70, enc so s; each 10-mph interval, and 100, 500, 1000,2000 , and $5000 \mathrm{ft}$.

Additional data can be saved in RAM if cesired. The data can then be output to tape and/or printed on - data terminal at the end of the run. Currently, 


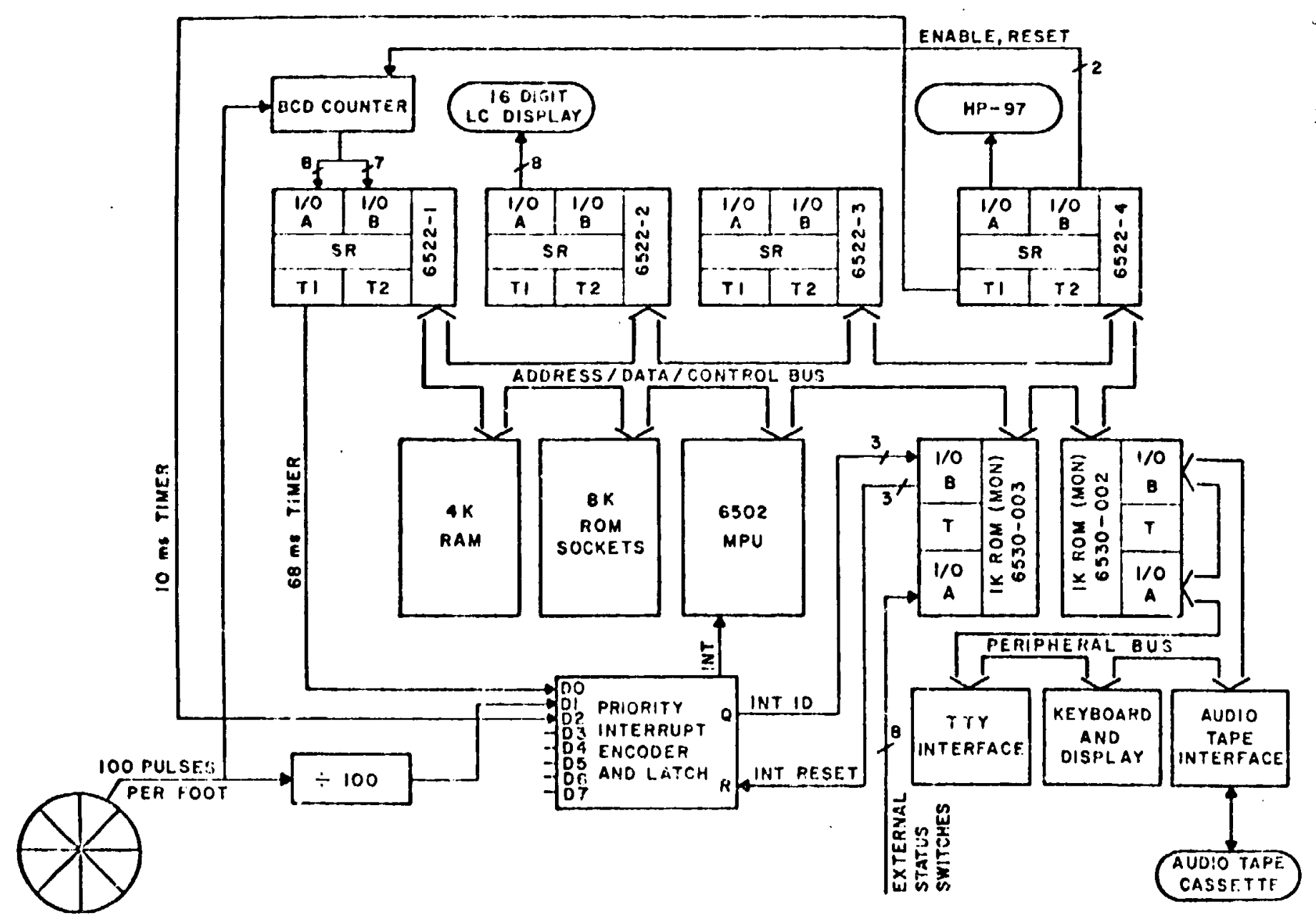

Fig. 2. Lamar Instruments computerized roal-less sy:tem.

time, velocity, and distance are saved each sccond and each wije per hour for both erceleration and coast down. In addition, deta is saved cvery $200 \mathrm{ft}$ for acceleration runs and every $500 \mathrm{ft}$ for coest revin. For most applications, saving data each secons: is icieguate. Both the print points and the sive points are softwire defined and can be easily changed.

The dato stored on tape can be processed by a number of systems. At Los Alarios rost of the dato was processed hy a HP-9820A cesk calculator with a S862A plotter. Some data processing was done with a $6502 \mathrm{mi}$ croprocessor system and some with a CDC 7600 conputer.

The keylloard and display can be used to address nemory, enter data, begin execution of a program, reset the system, or interriut the processor. The display consists of six 7-secment digits to display the address (4 digits) and data ( 2 digits).

A data terminal can be connected through the TTY Interface to enhance the 1/0 copabilities of the system. Specificaliy, a TI 73.3 ASK with a Tir to $5.5-232 C$ adanter is used, although other ITY 20-MA current loop or RS-232C compatible terminals can be used.

The audio tape is used to enter dato and programs into RAM or store them on tave. In acdition, the II 733 ASR can be used for tho sarre purpes? except that the tapes ere in odgitol forrat conpatitile with the Los Alamos Central Computing Facility as hell as most other data centers.

\section{Softwere Descripticn}

The major portions of the softwere are the initialization routine, the backgrour prourars that previde output to the LCU and the printer, the interiupt Io routinc, and the thirec interrunt service rout ines that uprite velocity, distance, and tine.

The turn-en scquence and beckground prograns are shown in Fig. 3. After the processor is initialized, the cefault print and seve values for time, velocity, and distance are londed frem ROF to RAli. Ones in RAli, these values can be chenerce if cesirec by means of the keyboard. The default values are stored in a" crasable PROH and are easily changed if an EPRCNi progranier is available.

The LCO-output routine updates the display with the current values of elansed tine, velocity, and elapsed distance. The display is updated every half second. If the display is uplated tco rapidly, reacability is reduced. The HP- 57 output rout ine sends data to the HP-97 as long as there is cata in the print buffer. Since there is no handshak ing with the HP-97, delays are used betheen output cormanus. A ciciny of $120 \mathrm{~ms}$ between each data character and a 1.28-5econd delay between print ccrimends provides reliable operation.

The interrupt identification routine first saves the accumlulator and the tho index registers, reads the 


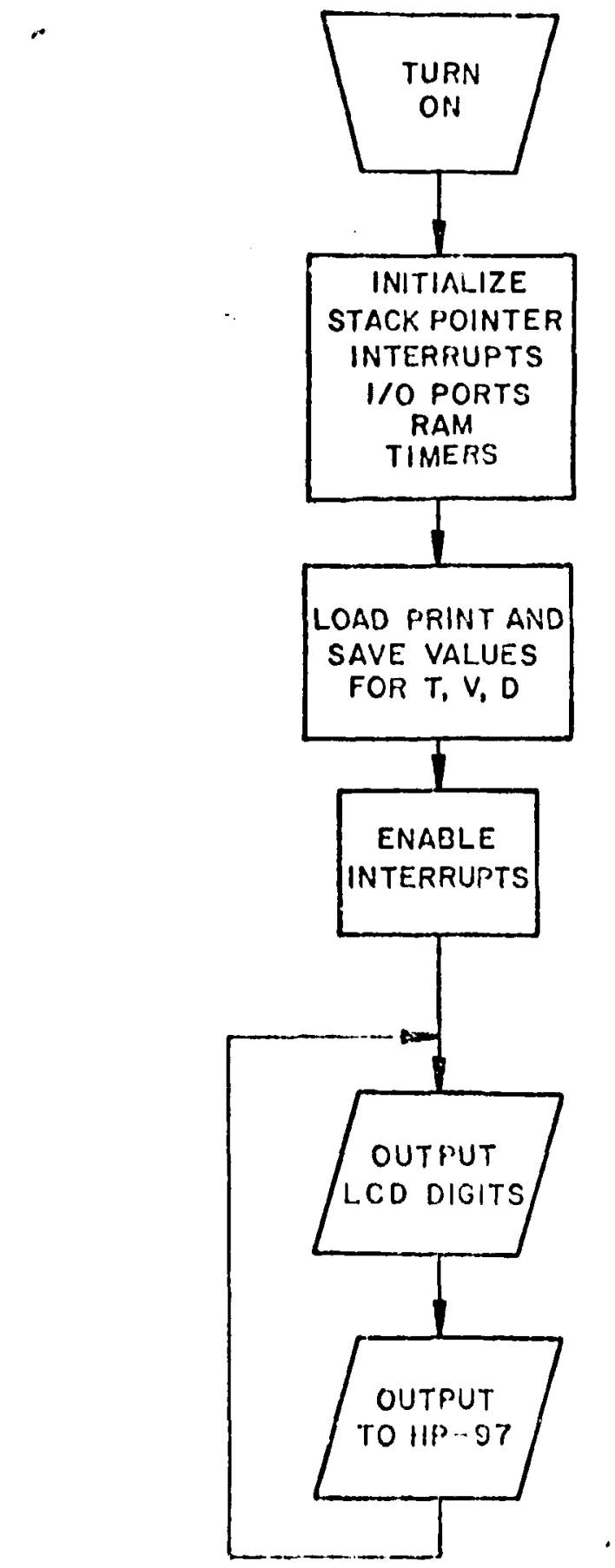

rig. 3. Initialization and hackground prograns.

external status switches, and reads the priority interrupt encoder. The reut ine then cetermines if the in. terrunt vide from the $E$ E-ns tirer, the foct counter, or the 10-r.s tirer and jume to the velocity distance or time service routine accordingly.

The interrupt service routines update velocity, distance, and time when requirco. A flow chert of the veluctly undete rount ine is shown in Fig. 4. This routine reads the ICO counter, stores ihe current value of velucity, coternines if o run is in progress (system in run and distence creater than $1 \mathrm{ft}$ ), saves cata if appropriate, resets the mph interrunt flog and returns. The fout and time routines increrent end storf distance or tilie when appropriate, icset the interiupt flig, arief returr: to the background program.
The $2 k$-byte ROM monitor, supplicd by RiCS lechnolory, peririts input and outmut throuch, tie: kcyboard arid cispley, a Tir corpatible cata terminel, ane an audio tape unit. Use of a 11 733ASR and RS-Z3EC adspter permits $1 / 0$ fren digital tape cassettes. The mrinitor also allews progran executicn to be started or stopped from the keyboard or the data terminal.

Some additicns to the MOS Technology monitor have hrin written that proyide:

Tre corvenient display of a mennory block on the ta terminal.

e menory block 1 to memory bleck 2 .

et nerrory bloct to a hex number,

Connare nic ory block to a hex number,

Compare nicmory block 1 to memory block 2, and

Faster dump of nemory block to audio tape.

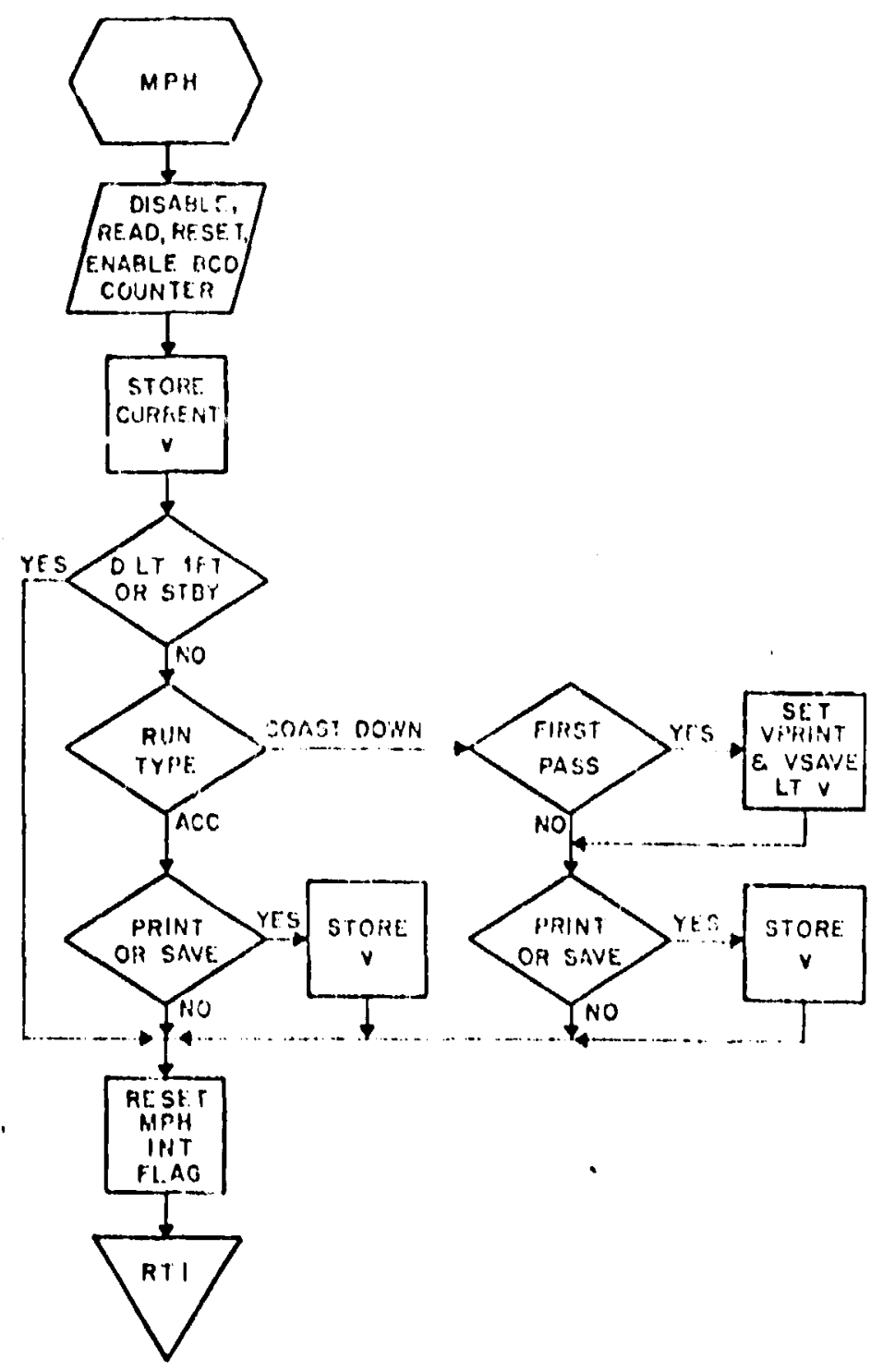

Fig. 1. Velocity updale rouine. 


\section{Conclusions}

The road-test systen descrited provicies rapid and detailed acquisition of accurate cata frei roll-down and acceleration test;. Straight-line whicle foriormance is characterized by fewer at the vilceels, rolling friction, and aerodynamic crig fli: aternal fictors such as wind and grade. Available roiner ci :l. "heels can be deterinined from wide oper throttle accelerd: tests. Rolling friction and aerociynamic erag can be determined fram ccast-down tests.

A fuel-cell pewered vehicle program at Los Alamos recuired that the performance of a number of vehicles be characterized. The roed-test systeri vas used for this rurpose. Sirice it is ricroprccessor based, the system is also intented to he used as an expenced dataacquisition system for a fuel-cell powered vehicle.

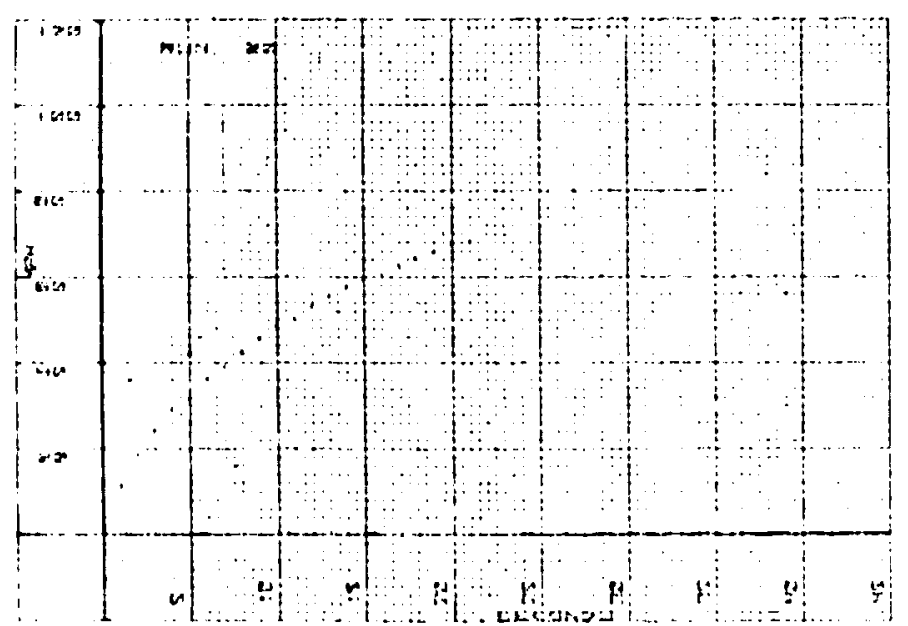

Fig. 5. Volkswagen Ribbil accoleration.
The first time the system was used, 12 vehicies vicere tested in 3 cays. A total of 103 rali-cein and 12 quarter lifile accelerition rulis vere i.ecte. Ir most of the tests one person drove tie vehicle ane cperated the road test system. Data was saved on tape at I s and I nile por hour intervals. Figures 5 and \& show acceleration and coast-dcren plots for $v$ verstis $t$ obi: ined from the tape data for a Volkswagen Rabbit.

Inc ines were used es input to a nuniber of daiareduction p.rwins.s. Most of the data reductir.r. was done on a cesk in.lllator with an ink pletter. Scme date processing waj 'so donc on a microprocesser system, and some on a lu: . "n conjuter.

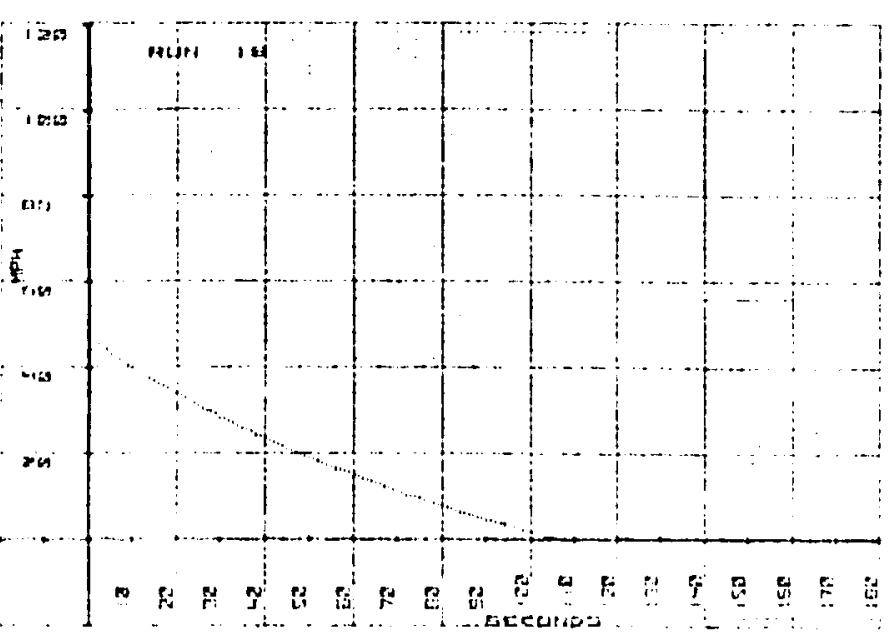

Fig. 6. Volkswagen Rabbit coast down. 


\section{Conclustons}

The road-test systom described providies roptd and

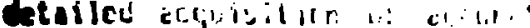

and accelerat lon test:. Sirolght-line vihicie firlorirance is cheracterizcd by licing at the biliants, 1011 ing frtacion, and acrodynamic crig clus cutarnal factors such as wind and arade. Avallibble power ci $: 11$. "heels

- can be determined Prom wide open throttle accelerdi cests. Rolling friction and anrorynamic drag can be deternined fram coast-down tests.

A fuel-cell powered vehicir pregrom at Los Alanos required that the performence of a numter of vehicles be charaeterized. The roed-lrist systeri was used for this purponse. Since tt is nicroprecessor basce. the system is oiso intended to be used as an expencied dataecquisition systern for a fuel-coll prwerid vehicle.

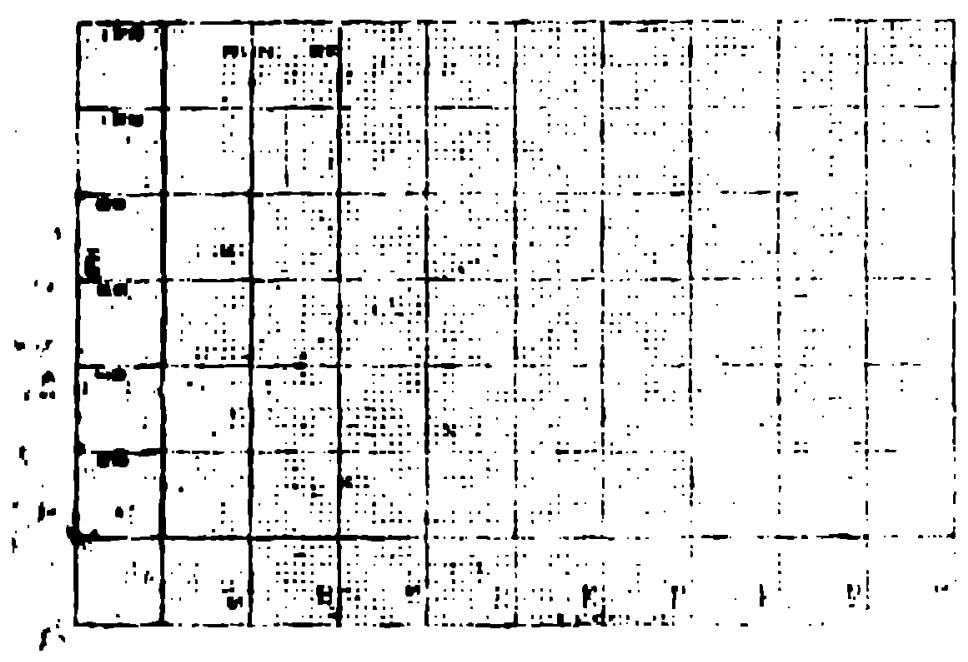

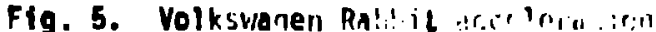

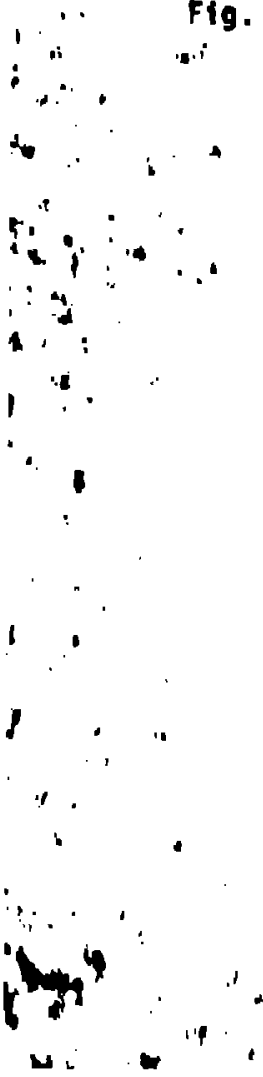

The first eire the syetco was used, if velilcles I intal of $15:$ yell-dewt entet

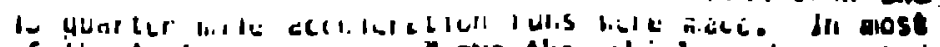

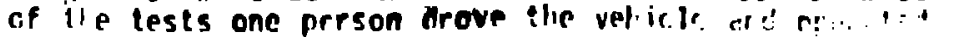

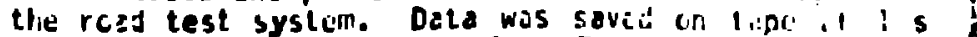
and 1 rille per hour Iruervals. Figures 5 end 6 sdiow acceleration and coast-conn plots for $v$ versus $t a b$ istned from the tape data for a Volkswagen Rabbit.

I1: is nes were used as input to a number of dotereduction j. M.....i.s. Most of the date reduction was doric on e desk $\left.C^{-}-1\right)$ lator with an ink pletter. Some date rrecessing wa: $-9,0$ done on miteropro-essor system, arid some on a $\mathrm{Cr}_{2}$. " mn computer.

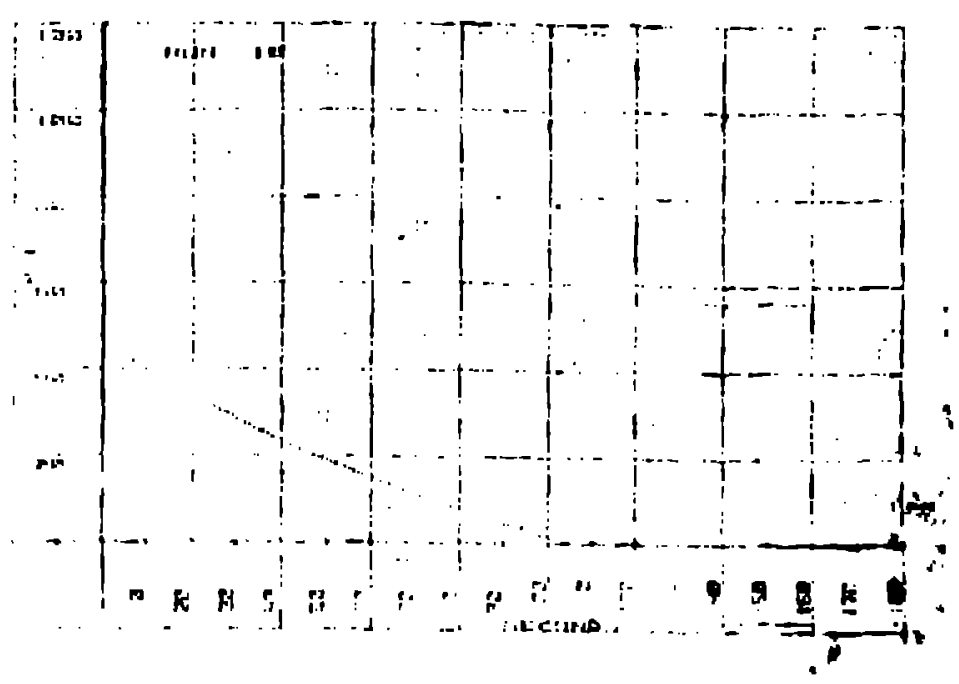

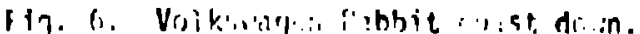

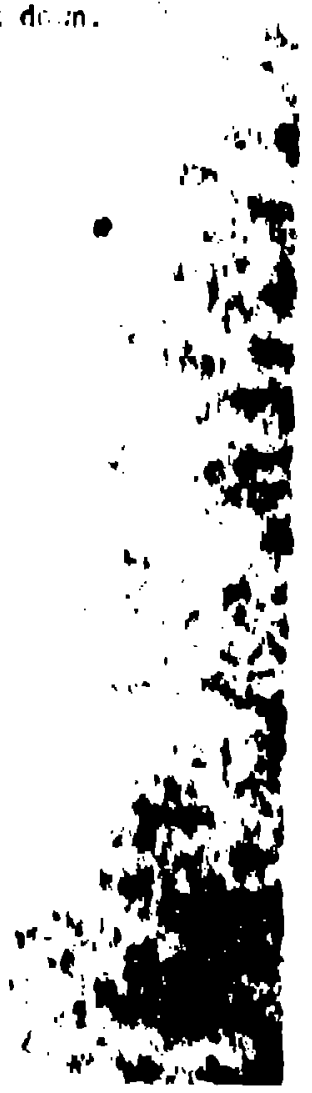

